\title{
Attraction of Scarabaeinae (Coleoptera: Scarabaeidae) to different baits in the Brazilian Amazon region
}

\author{
Reinaldo L. Cajaiba ${ }^{1,3^{*}}$, Eduardo Périco ${ }^{1}$, Wully B. da Silva ${ }^{2} \&$ Mário Santos $^{3}$ \\ 1. University Center Univates, R. AvelinoTallini, 95900-000, Lajeado, RS, Brazil; reinaldocajaiba@hotmail.com, \\ perico@univates.br \\ 2. Federal University of Pará, R. Cel. José Porfírio, 2515, 68371-040, Altamira - PA, Brazil; wully_bio@hotmail.com \\ 3. Laboratory of Applied Ecology, CITAB - Centre for the Research and Technology of Agro-Environment and \\ Biological Sciences, University of Trás-os-Montes e Alto Douro, 5000-911, Vila Real, Portugal; \\ mgsantoss@gmail.com \\ * Correspondence
}

Received 02-XII-2016. Corrected 29-III-2017. Accepted 27-IV-2017.

\begin{abstract}
Dung beetles (Coleoptera: Scarabaeidae: Scarabaeinae) are considered essential for enhancing the physicochemical characteristics of soils, principally by changing organic materials (e.g. dead animals, faeces, fruits e leaf litter). This study compared the species richness and abundance of dung beetles captured using various types of baits, to demonstrate attractiveness differences in variable habitats of the Brazilian Amazon. Samplings were carried out with pitfall traps baited with human faeces, rotten banana, rotten meat and a nonbaited trap, in February, March, June, September and October 2015. Habitats included native forests, agriculture areas, pastures and disturbed forests in different regeneration stages. A total of 13736 Scarabaeinae beetles were captured, distributed over 98 species. Most individuals were captured using traps baited with faeces $(76.7 \%$ of individuals), followed by rotten meat baited traps (17.8\% of individuals), fermented banana baited traps (3.9\% of individuals) and finally by non-baited traps (1.6\% of individuals). A significant difference in attractiveness of the different baits used and habitats types was observed. Most of the captured assemblages were composed by coprophagous (42\%), generalist species (32\%), necrophagous (15\%) and none was classified as saprophagous. Approximately $54 \%$ of the specimens were tunnelers, $25 \%$ were rollers and $12 \%$ were dwellers. The species of Scarabaeinae sampled in the region revealed qualitative and quantitative differences among their assemblages and the phytophysiognomies. The forest environments housed the greatest species richness observed, and a fraction of these is exclusive of those areas. We concluded that some species of Scarabaeinae have an important potential as disturbance indicators in the Amazonian ecosystem. Rev. Biol. Trop. 65 (3): 917-924. Epub 2017 September 01.
\end{abstract}

Key words: dung beetles, dung attractiveness, food preference, trophic guild, tropical forest.

The subfamily Scarabaeinae (Coleoptera: Scarabaeidae) includes dung beetles (DB), a globally distributed group of detritus-feeding insects, determinant of ecological functions such as nutrient recycling, secondary seed dispersal, bioturbation, and natural control of cattle parasites (Nichols et al., 2008; Simmons \& Ridsdill-Smith, 2011). Their contribution to the improvement of the physico-chemical properties of the soil and plants is associated with increased edaphic aeration and hydration (Andresen, 2002; Nichols et al., 2008).

Mammalian dung is one of the most important food resources for dung beetle communities, being also the dominant substrate for oviposition (Filgueiras, Liberal, Aguiar, Hernández, \& Iannuzzi, 2009). Anyhow, in the Neotropics, fungi, plants and carcasses are also used by several species as food resource (Halffter \& Matthews, 1966). This seems related 
to the local availability of the ecosystem that provides food for the maintenance of diverse DB strategies. When the food source is not available due to various limiting factors, several DB can use other similar state resources (in the process of decomposition) as food ( $\mathrm{Da}$ Silva \& Audino, 2011). This feeding diversification observed in the Neotropics is believed to have occurred during the extinction of large mammals in the late Pleistocene (Halffter, 1991; Larsen, Lopera, \& Forsyth, 2006).

In tropical regions, the main types of baits used for monitoring DB are cattle dung (Andresen, 2008; Ueda, Dwibadra, Noerdjito, Kon, \& Fukuyama, 2015) and human faeces (Vieira, Louzada, \& Spector, 2008). Alternative baits have included the dung of other mammals, rotting fruits (Vieira et al., 2008; Ueda et al., 2015) and carrion (Ueda et al., 2015). Different food preferences reduce inter specific competition, allowing the coexistence of diverse DB species, in particular neotropical ecosystems. Indeed the occupation of diverse ecological niches increases diversity for specific locations (Da Silva \& Audino, 2011). The presence/ abundance and type of food types, associated with other factors such as climate, animal migrations and life cycles, in addition to altitude and landscape features, might affect the spatial and temporal distribution of Scarabaeinae (Filgueiras et al., 2009).

The use of DB in the Brazilian Amazon is in its initial stage, despite already having a reasonable number of publications associated, mostly restricted to the South and Southeast part of the country. Furthermore, the DB research and applications could be significantly improved through using standardized methods and data sets, supported on the species preferences and patterns of functional response to disturbance (Cajaiba, Perico, Cabral, \& Santos, 2015a). In fact, understating food preferences of DB assemblages is fundamental to enlighten managers on the effects of changes occurring in tropical regions. The use of trophic guilds/ functional guilds (necrophagous, saprophagous, coprophagous, tunnelers, dwellers and rollers) may also reveal interesting differences in the structure and functioning of ecosystems and landscape (Paoletti, 1999).

The present study compared the DB richness, abundance and functional diversity when captured using different types of baits in variable habitats of the Brazilian Amazon, in order to: a) assess the general attractiveness of baits, and b) gauge the relation between specific baits' diversity and the dominant habitats. The presented method and results could be used to support a standardization of field work for effective ecological monitoring of this group studies in Neotropical areas.

\section{MATERIAL AND METHODS}

Study sites: The study was performed in the municipality of Uruará, state of Pará, Northern Brazil (-0343'27' S - 53⒋' '8' W). The dominant land use/land cover of the study area was a natural forest ( $69 \%$ of the area), where deforestation is mainly concentrated in the South-central part of the territory, near the main roads. Extensive livestock production and the exploitation of timber at a large scale (mostly illegal) are currently considered the most serious environmental threats (Cajaiba, Cabral, $\&$ Santos, 2015b). The studied areas encompass habitats that, in terms of physical characteristics and anthropogenic disturbances, are representative of the regional habitas: Native Vegetation-NV, Mature Secondary successionMS (vegetation with 15 years of regeneration), Early Secondary succession-ES (vegetation with five years of regeneration), AgricultureAg (cocoa plantations, Theobroma cacao L.) and Pasture for extensive livestock-Pa. This habitats gradient was considered fundamental to analyse the response of DB communities (Cajaiba et al., 2015b). The climate of the study area is classified as Aw (Köppen), hot and humid and the average annual rainfall is 2000 mm (Peel, Finlayson, \& Mcmahon, 2007).

Sampling method: Sampling was carried out during the year 2015, in the months of February, March, June, September and October. The sample points were placed at a minimum 
distance of 100 meters from ecotones, to guarantee that most DB captured in the pitfalls were associated to the specific LU/LC monitored. Pitfall traps $(75 \mathrm{~mm}$ diameter and $110 \mathrm{~mm}$ deep) were filled with preservative liquid consisting of formalin, alcohol, water and a few drops of detergent to break the surface tension (Cajaiba et al., 2015b). A roof was attached to each pitfall to prevent rainwater from entering, remaining installed for $48 \mathrm{~h}$ prior to collection. Each pitfall contained different baits: Human faeces-HF; Rotten meat-RM; Rotten banana$\mathrm{RB}$ in order to attract different species according to their feeding habits and non-baited pitfalls were used as control-Co.

In each study site (NV, ES, MS, Ag and $\mathrm{Pa}$ ) seven sample points were placed $100 \mathrm{~m}$ apart. Each sample point contained four pitfall traps separated by five meters and included the different baits (HF, RM, RB, Co). The distance between pitfall traps allowed individuals to choose their preferential food resource (Almeida \& Louzada, 2009; Da Silva, Vaz-De-Mello, \& Di Mare, 2012). The Scarabaeinae collected were conserved in $70 \%$ ethanol and taken into the laboratory and identified to the species level when possible. The identification was based on the keys proposed by Vaz-de-Mello, Edmonds, Campo, and Schoolmeesters (2011) and Pacheco and Vaz-de-Mello (2015).

Species were classified within guilds, according to their use of food and nesting resources. Nesting guild included rollers (those that roll balls of food on the surface of soil to some distance from the source of resource, where they bury them); tunnelers (those that carry food resource into the soil, making tunnels on the side or below the resource); and dwellers (which do not reallocate food, using it directly in the source) (Simmons \& RidsdillSmith, 2011; Da Silva \& Di Mare, 2012). Concerning the feeding guild, species were classified as coprophagous ( $\geq 80 \%$ of captures occurred in traps baited with faeces), necrophagous ( $\geq 80 \%$ of captures occurred in traps baited with rotten meat), saprophages ( $\geq 80 \%$ of captures occurred in traps baited with rotten banana) and generalists (species not covered in the previous groups) (Almeida \& Louzada, 2009; Da Silva \& Di Mare, 2012).

Two way analysis of variance (ANOVA)/ Kruskal-Wallis tests, and associated multiple comparisons tests, Tuckey and Dunn were used for testing: a) possible differences of nesting guild selection (tunnelers, dweller, rollers) and feeding guild selection (coprophagous, necrophagous, saprophages and generalist) within the different habitats; b) possible differences in richness and abundance of Scarabaeinae by bait, and c) differences in abundance and richness of the Scarabaeinae by baits within the habitats studied. The normality of the data was verified by the Shapiro-Wilk test. In order to homogenize the variances and normalize the residues, both the abundance and richness changed to logarithmic values $(\log +1)$. All analyses were performed using PAST software version 3.14 (Hammer, Harper, \& Ryan, 2001).

\section{RESULTS}

General results/Functional diversity: A total of 98 species and 13736 scarabaeine beetles were captured. The most abundant species were Canthidium deyrollei Harold 1867 (985 individuals), Canthidium sp. 4 (890 individuals), Dichotomius sp.1 (701 individuals), Ateuchus murrayi Harold 1868 (666 individuals), Ontherus carinifrons Luederwaldt 1930 (664 individuals) and Deltochilum submetallicum Castelnau 1840 (612 individuals). Of the total number of collected individuals, $76.7 \%$ were captured in faeces baited traps, $17.8 \%$ in rotten meat traps, $3.9 \%$ in rotten banana traps, and only $1.6 \%$ in non-baited traps. Eight species were captured in all traps.

Considering the feeding guild, coprophagous comprised $42 \%$ of the collected specimens, $32 \%$ were considered generalists, and only $15 \%$ were determined as necrophagous (Appendix). The coprophagous were more abundant in NV when compared to other habitats $\left(\mathrm{F}_{4,205}=12.35, \mathrm{P}<0.001\right)$, namely between $\mathrm{NV}$ vs MS (Q 5.69, $\mathrm{P}<0.01)$, NV vs ES (Q $8.12, \mathrm{P}<0.001), \mathrm{NV}$ vs $\mathrm{Pa}(\mathrm{Q} 7.83, \mathrm{P}<0.001)$ and NV vs Ag (Q 8.33, P<0.0001). Generalists 
were also more abundant in NV when compared to other habitats $\left(\mathrm{F}_{4,155}=12.75, \mathrm{P}<\right.$ $0.05)$, specifically between NV vs MS (Q 5.52, $\mathrm{P}<0.05$ ), NV vs ES (Q 8.32, $\mathrm{P}<0.001)$, NV vs $\mathrm{Pa}(\mathrm{Q} 7.53, \mathrm{P}<0.001)$ and $\mathrm{NV}$ vs $\mathrm{Ag}(\mathrm{Q}$ $8.65, \mathrm{P}<0.0001)$. In relation to the necrophagous abundance, no statistical differences were detected $\left(\mathrm{F}_{4,70}=2.40, \mathrm{P}=0.06\right)$ (Fig. 1).

Concerning the nesting guild, approximately $54 \%$ of the specimens (53 species) were tunnelers, $25 \%$ were rollers ( 25 species) and $12 \%$ were dwellers (12 species). The tunnelers were more abundant in $\mathrm{NV}$ when compared to other habitats $\left(\mathrm{F}_{4,255}=18.04, \mathrm{P}<\right.$ 0.05 ), namely between NV vs MS (Q 6.61, P < 0.05 ), NV vs ES (Q 9.87, $\mathrm{P}<0.05$ ), NV vs $\mathrm{Pa}$ (Q 9.52, $\mathrm{P}<0.05$ ) and NV vs Ag (Q 9.92, $\mathrm{P}<$ $0.001)$. The number of rollers was significantly higher in $\mathrm{NV}\left(\mathrm{F}_{4,124}=2.82, \mathrm{P}=0.02\right)$, with significant differences between NV vs ES (Q 3.93, $\mathrm{P}=0.04)$ and $\mathrm{NV}$ vs Ag $(\mathrm{Q} 4.26, \mathrm{P}=0.02)$. Due to the low abundance of dweller species (12 species) it was not possible to perform statistical analysis (Fig. 2).

Bait atractivness: Kruskal-Wallis tests showed significant statistical differences in the medians of species richness by bait types (Kruskal-Wallis $=252.8$, d.f. $=3, \mathrm{P}<0.01$ ). According to an a posteriori Dunn's test, significant differences were found between medians of HF vs RM $(71.59, \mathrm{P}<0.05)$, HF vs RB (146.59, $\mathrm{P}<0.01)$, HF vs Co $(160.79, \mathrm{P}<$ $0.0001), \mathrm{RM}$ vs RB (75.01, $\mathrm{P}<0.01)$, RM vs Co (89.20, $\mathrm{P}<0.01)$. There was no difference between RB and Co (14.20, P > 0.05) (Fig. 3A).

Kruskal-Wallis tests also showed significant statistical differences in the medians of species abundance by bait types (KruskalWallis $=252.8$, d.f. $=3, \mathrm{P}<0.01)$. Significant differences were found between medians of HF vs RM (52.22, $\mathrm{P}<0.05)$, HF vs RB (193.87, $\mathrm{P}$ $<0.001)$, HF vs Co (225.05, $\mathrm{P}<0.0001)$, RM vs RB (141.64, $\mathrm{P}<0.01)$, RM vs Co (172.84, $\mathrm{P}<0.05)$. There was no difference between the average RB vs Co (31.20, $\mathrm{P}>0.05)$ (Fig. 3B).

When the richness of the Scarabaeinae was tested for the different kinds of baits

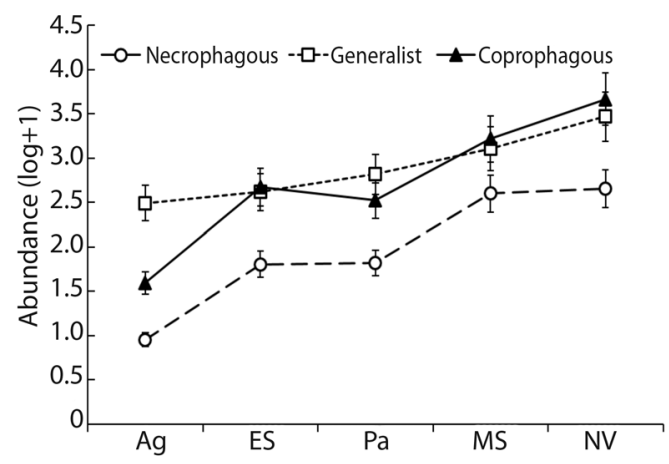

Fig. 1. Abundance of Scarabaeinae feeding guilds by habitat. NV: Native vegetation; MS: Mature secondary; ES: Early secondary; Ag: Agriculture (Cocoa); Pa: Pasture.

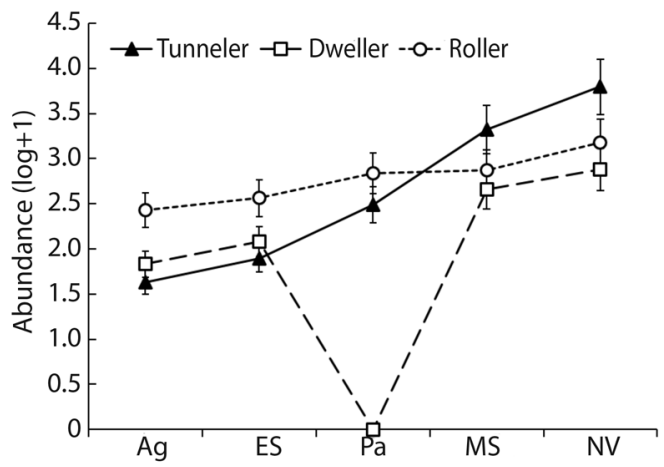

Fig. 2. Abundance of Scarabaeinae on the behavioral guild in different habitats studied. NV: Native vegetation; MS: Mature secondary; ES: Early secondary; Ag: Agriculture (Cocoa); Pa: Pasture.

among habitats, significant differences among bait types $(\mathrm{F}=51.71$, d.f. $=3, \mathrm{P}<0.001)$ and habitats $(\mathrm{F}=29.1$, d.f. $=4, \mathrm{P}<0.001)$ were found (Fig. 4A). When the abundance of the Scarabaeinae was tested for the different kinds of bait among habitats, significant differences among bait types $(\mathrm{F}=61.2$, d.f. $=3, \mathrm{P}<0.01)$ and habitats $(\mathrm{F}=47.18$, d.f. $=4, \mathrm{P}=0.001)$ were found (Fig. 4B).

\section{DISCUSSION}

Considering the functional diversity, this work revealed that conserved environments 

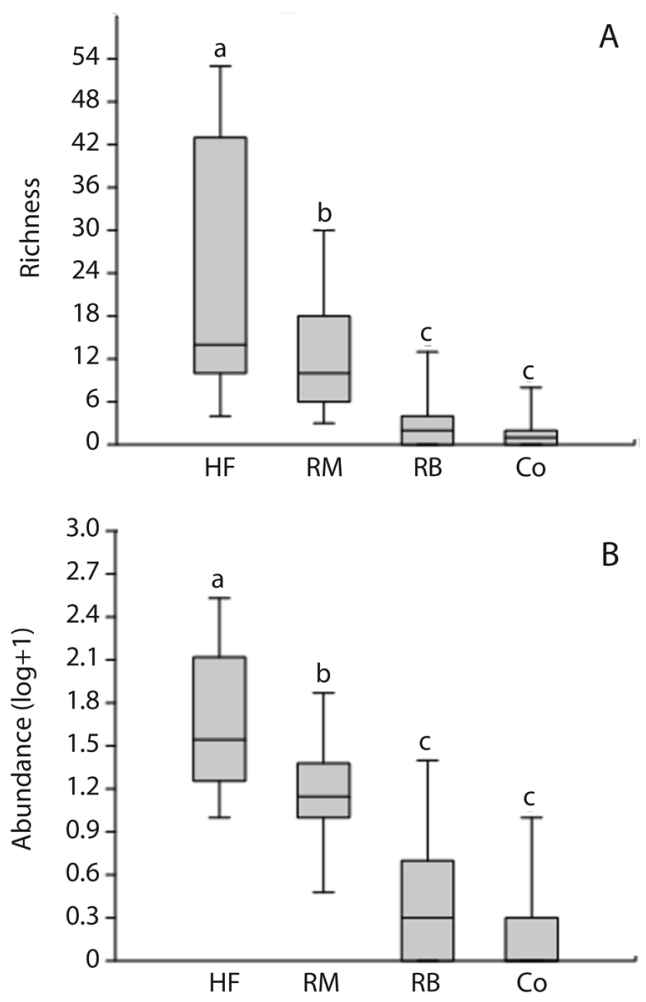

Fig. 3. Differences between abundance (A) and species richness (B) of the Scarabaeinae studied with different bait type. Co: Control bait; RB: Rotten banana; RM: Rotten meat; HF: Human faeces. The values followed by the same letters are not different according to Dunn test.

such as NV and MS in this region, hold a larger proportion of Dung Beetle (DB) tunnelers, rollers and dwellers. Anthropogenic disturbances may alter the composition of scarabaeines, changing the primary "services" of dung beetles such as the reduction and decomposition of organic materials through burial and removal. These actions are fundamental for the conversion of biomasses, conserving energy and recycling nutrients in the ecosystem (Arellano, 2016). This group is also involved in other functions which include reducing compaction and improving soil fertility, dispersal of seeds, control of vectors of diseases (e.g. flies) and protection of agricultural/wild seeds against pests (Nichols et al., 2008).

Human actions that reduce specific mammal groups may have direct effects on DB
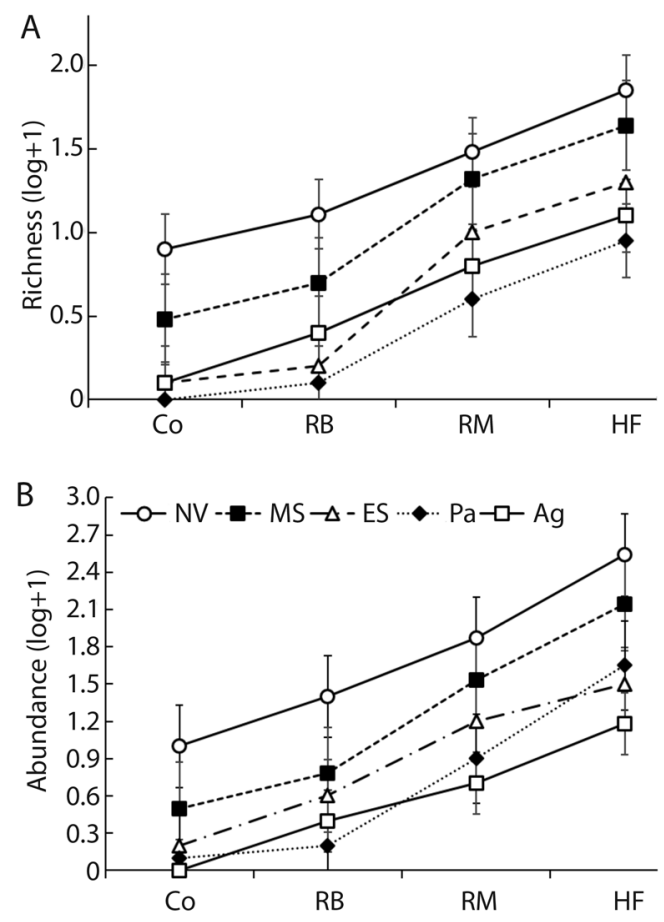

Fig. 4. Differences between species richness (a) and abundance (b) of the Scarabaeinae studied in different habitats $(\mathrm{NV}=$ Native vegetation, $\mathrm{MS}=$ Mature secondary, $\mathrm{ES}=$ Early secondary, $\mathrm{Ag}=$ Agriculture, $\mathrm{Pa}=$ Pasture) for each bait type $(\mathrm{Co}=\mathrm{Control}$ bait, $\mathrm{RB}=$ Rotten banana, $\mathrm{RM}=$ Rotten meat, $\mathrm{HF}=$ Human feces).

fauna, which in turn may alter nutrient cycling processes and secondary dispersion of seeds (Andresen, 2002). In addition, the biological effects of a reduction in fauna may impact processes (e.g. behavioural / physiological, ecological, and evolutionary) at different environmental scales (e.g., local, regional, ecosystemic, and global) (Galetti \& Dirzo, 2013; Bogoni \& Hernández, 2014). The high coprophagy specialization in the Scarabaeinae seems to be related to the regular availability of mammal dung in the ecosystem (Halffter \& Matthews, 1966) contrary to the rotting fruits and carcasses of dead animals that might be seasonally and spatially limited (Louzada \& Lopes, 1997). Considering that an important proportion of the nutrients consumed by vertebrates remain in their faeces and leftovers (Steinfeld et al., 2006), the ecological 
function performed by DB is fundamental for nutrient cycles and ecosystem productivity (Huerta, Martínez, Montes, \& Favila, 2013; Arellano, 2016). For example if fresh dung is not rapidly incorporated into the soil, most nitrogen is lost through ammonia volatilization (West \& Nelson, 2003).

Although generalists, several species present feeding preferences for certain types of resource (Da Silva et al., 2012). In fact, tunnelers were dominant in relation to the other guilds, a common pattern in the Neotropics. The distribution of behavioral guilds seems to be the result of local diversity of DB species in the Neotropics (Louzada \& Lopes, 1997; Lima, Silva, Bianch, Da Silva, \& Di Mare, 2015).

When considering bait attractiveness, Halffter and Edmonds (1982) suggested that DB have physiological needs at different times of the year due to their life cycle, which may also explain the use of different food resources (Da Silva \& Di Mare, 2012). Anyway, a clear distinction of attractiveness of the different types of baits to Scarabaeinae within habitats was detected. HF presented the highest abundance and richness in all habitats. In fact, the majority of collected individuals were coprophagous, i.e. preferred stool baits. The results obtained are in agreement with other studies in tropical forests and in other types of landscapes in tropical regions (Halffter \& Matthews, 1966; Filgueiras et al., 2009; Da Silva et al., 2012). The preference for faeces of omnivorous mammals for nesting and feeding by adults and larvae seems to have resulted from evolutionary processes (Simmons \& Ridsdill-Smith, 2011; Da Silva et al., 2012; Da Silva \& Di Mare, 2012). This perspective suggests that loss of mammals (i.e., and their feces as a food resource) may alter competitive interactions between dung beetles species and may even cause local extinction of highly specialized species (Bogoni \& Hernández, 2014). RM baits were also quite attractive highlighting the importance of this group in nutrient cycling processes in the environments where they live: according to Halffter and Matthews (1966) and Da Silva and Di Mare (2012) species of DB that feed on dead animal evolved with scarcity of large mammals and lower supply of excrement in the Neotropics (Halffter, 1991).

Traps with bait tend to be selective: if the aim of a specific work is an assessment of the overall community, different baits should be used to collect most diversity and estimate relative abundances (Rafael, 2002); if the goal of the research is collecting specific species and/or groups (e.g. trophic/functional guilds), particular baits should be used (Marchiori, 2016). Collection methodologies described here provide an approach to improve the detection and description of the responses of DB to disturbance and anthropogenic pressures, and facilitate a greater integration of ecological data collection efforts in tropical regions. Although spatially and temporally restricted, the results of this study highpoint the attractiveness of several baits and the feeding preference of some species of DB.

Although highly specialized in mammalian excrement due to evolutionary processes, many Neotropical species of Scarabaeinae show plasticity in their diet (Larsen et al., 2006). This process seems related to the local availability of the ecosystem to provide food, i.e... when the preferred food is not available, due to different limiting factors, many Scarabaeinae may use other resources in similar state (in decomposition process).

The DB sampled in the Amazon region reveal qualitative and quantitative differences among their assemblages and the phytophysiognomies sampled. The forest environments housed the greatest species richness observed and a fraction of these is exclusive of this environment and hardly occurs in other types of ecosystems (Cajaiba et al. unpublished). However, another part of this fauna is adapted to the open environment, being largely represented by coprophagy species. In this way, the landscape context is very important to the $\mathrm{DB}$, because complementarity of habitats can present a particular diversity that increases the diversity of the landscape (Almeida \& Louzada, 2009). Studies like this, focused in the knowledge of the biology and distribution of Scarabaeinae, 
are essential to support any future initiative for biodiversity and ecosystems conservation ( $\mathrm{Da}$ Silva et al., 2012; Lima et al., 2015).

\section{RESUMEN}

\begin{abstract}
Atracción de Scarabaeinae (Coleoptera: Scarabaeidae) por diferentes cebos en la región Amazónica brasileña. Los escarabajos peloteros (Coleoptera: Scarabaeidae: Scarabaeinae) son considerados fundamentales para la mejora de las características físico-químicas de los suelos, es decir, para la descomposición de materiales orgánicos (p. ej., animales muertos, heces, frutas y hojarasca). Este estudio compara la riqueza de especies y la abundancia de escarabajos peloteros, capturados utilizando diversos tipos de cebos, para demostrar diferencias en la atracción en hábitats de la Amazonía Brasileña. Se realizaron muestreos con trampas cebadas con heces humanas, plátano podrido, carne podrida y una trampa sin cebo. Los hábitats incluyen bosques nativos, zonas de agricultura, pastos y bosques alterados en diferentes fases de regeneración. Se capturaron un total de 13736 escarabajos Scarabaeinae, distribuidos en 98 especies. La mayoría de los individuos fueron capturados en trampas cebadas con heces $(76.7 \%$ de los individos), seguido por las trampas con cebo de carne podrida ( $17.8 \%$ de los individuos), trampas con cebo de plátano fermentado (3.9 \% de los individuos) y finalmente por las trampas sin cebo (1.6\% de los individuos). Se observó una diferencia significativa en la atracción de los diferentes cebos y hábitats. La mayoría de la comunidad capturada estuvo compuesta de escarabajos coprófagos (42\%), especies generalistas (32\%) y necrófagos (15\%) y ninguno fue clasificado como saprófago. Aproximadamente, el $54 \%$ de las muestras fueron excavadores, $25 \%$ rodadores y $12 \%$ residentes. Las especies de scarabaeinae muestreadas en la región revelaron diferencias cualitativas y cuantitativas entre sus ensamblajes y las fitofisionomías muestreadas. Los ambientes forestales albergaron la mayor riqueza de especies observada y una fracción de ellas es exclusiva de este entorno. Concluimos que algunas especies de Scarabaeinae tienen un potencial importante como indicadores de alteración en el ecosistema amazónico.
\end{abstract}

Palabras clave: escarabajos peloteros, atracción del estiércol, preferencia de alimentación, agrupación trófica, bosque tropical.

\section{REFERENCES}

Almeida, S. S. P., \& Louzada, J. N. C. (2009). Estrutura da comunidade de Scarabaeinae (Scarabaeidae: Coleoptera) em fitofisionomias do Cerrado e sua importância para a conservação. Neotropical Entomology, 38, 32-43.
Andresen, E. (2002). Dung beetles in a Central Amazonian rainforest and their ecological role as secondary seed dispersers. Ecological Entomology, 27, 257-270.

Andresen, E. (2008). Dung beetle assemblages in primary forest and disturbed habitats in a tropical dry landscape in western Mexico. Journal Insect of Conservation, 12, 639-650.

Arellano, L. (2016). A Novel method for measuring dung removal by tunneler dung beetles (Coleoptera: Scarabaeidae: Scarabaeinae) in pastures. The Coleopterists Bulletin, 70, 185-188.

Bogoni, J. A., \& Hernández, I. M. (2014). Attractiveness of native mammal's faeces of different trophic guilds to dung beetles (Coleoptera: Scarabaeinae). Journal of Insect Science, 14, 1-7.

Cajaiba, R. L., Cabral, J. A., \& Santos, M. (2015b). A minimal invasive method to forecast the effects of anthropogenic disturbance on tropical cave beetle communities. Neotropical Entomology, 4, 1-9.

Cajaiba, R. L., Perico, E., Cabral, J. A., \& Santos, M. (2015a). Assessing the potential role of ground beetles (Coleoptera) as ecological indicators in tropical ecosystems: A review (pp. 51-84). In C. Starck (Ed.), Beetles: Biodiversity, ecology and role in the environment (1ed, v. 1.). New York, Nova Science Publishers.

Da Silva, P. G., \& Audino, L. D. (2011). Escarabeíneos (Coleoptera: Scarabaeidae) atraídos a diferentes iscas em campo nativo de Bagé, Rio Grande do Sul, Brasil. Revista Brasileira de Zoociências, 13, 241-247.

Da Silva, P. G., \& Di Mare, R. A. (2012). Escarabeíneos copro-necrófagos (Coleoptera, Scarabaeidae, Scarabaeinae) de fragmentos de Mata Atlântica em Silveira Martins, Rio Grande do Sul, Brasil. Iheringia Serie Zoologia, 102, 197-205.

Da Silva, P. G., Vaz-De-Mello, F. Z., \& Di Mare, R. A. (2012). Attractiveness of Different Bait to the Scarabaeinae (Coleoptera: Scarabaeidae) in Forest Fragments in Extreme Southern Brazil. Zoological Studies, 51, 429-441.

Filgueiras, B. K. C., Liberal, C. N., Aguiar, C. D., Hernández, M. M., \& Iannuzzi, L. (2009). Attractivity of omnivore, carnivore and herbivore mammalian dung to Scarabaeinae (Coleoptera, Scarabaeidae) in a tropical Atlantic rainforest remnant. Revista Brasileira de Entomologia, 53, 422-427.

Galetti, M., \& Dirzo, R. (2013), Ecological and evolutionary consequences of living in a defaunated world. Biological Conservation, 163, 1-6.

Halffter, G. (1991). Historical and ecological factors determining the geographical distribution of beetles (Coleoptera: Scarabaeidae: Scarabaeinae). Folia Entomologica Mexicana, 82, 195-238. 
Halffter, G., \& Edmonds, W. D. (1982). The nesting behavior of dung beetles (Scarabaeinae): an ecologic and evolutive approach. México D.F., Mexico: Man and Biosphere Program Unesco.

Halffter, G., \& Matthews, E. G. (1966). The natural history of dung beetles of the subfamily Scarabaeinae (Coleoptera: Scarabaeidae). Folia Entomologica Mexicana, 12, 1-312.

Hammer, O., Harper, D. A. T, \& Ryan, P. D. (2001). PAST: Paleontological Statistics Software Package for Education and Data Analysis. Palaeontologia Electronica, 4, 1-9.

Huerta, C., Martínez, M. I., Montes, O. E., \& Favila, M. E. (2013). The role of dung beetles in the sustainability of pasture and grasslands (pp. 441-463). In A. Yáñez-Arancibia, R. Dávalos-Sotelo, J. W. Day, \& E. Reyes (Eds.), Ecological Dimensions for Sustainable Socio Economic Development. Boston, MA: WitPress, Southampton.

Larsen, T. H., Lopera, A., \& Forsyth, A. (2006). Extreme trophic and habitat specialization by Peruvian dung beetles (Coleoptera: Scarabaeidae: Scarabaeinae). The Coleopterists Bulletin, 60, 315-324.

Lima, J. D. N., Silva, V. C., Bianch, V., Da Silva, P. G., \& Di Mare, R. A. (2015). Estrutura e organização de assembleias de Scarabaeinae (Coleoptera, Scarabaeidae) em diferentes fitofisionomias no sul do Brasil. Iheringia, Série Zoologia, 105, 393-402.

Louzada, J. N. C., \& Lopes, F. S. (1997). A comunidade de Scarabaeidae copro-necrófagos (Coleoptera) de um fragmento de Mata Atlântica. Revista Brasileira de Entomologia, 41, 117-121.

Marchiori, C. H. (2016). Técnicas de coleta e captura de insetos das ordens Diptera e Hymenoptera coletadas no estado de Goiás. Biológico, 78, 1-5.

Nichols, E., Spector, S., Louzada, J., Larsen, T., Amézquita, S., \& Favila, M. E. (2008). Ecological functions and ecosystem services provided by Scarabaeinae dung beetles. Biological Conservation, 141, 1461-1474.

Pacheco, T. L., \& Vaz-de-Mello, F. Z. (2015). Dung beetles of the tribe Phanaeini (Coleoptera: Scarabaeidade: Scarabaeinae) from Roraima state, Northern Brazil: checklist and key to species. Biota Neotropica, 15(2), e20140145.

Paoletti, M. G. (1999). Using bioindicators based on biodiversity to assess landscape sustainability. Agriculture, Ecosystems and Environment, 74, 1-18.

Peel, M. C., Finlayson, B. L., \& Mcmahon, T. A. (2007). Updated world map of the Köppen-Geiger climate classification. Hydrology and Earth System Sciences, $11,1633-1644$

Rafael, J. A. (2002). A amostragem. Protocolo e técnicas de captura de Diptera. (2th.ed., pp. 301-304), Zaragoza: PrIBES.

Simmons, L. W., \& Ridsdill-Smith, T. J. (2011). Reproductive competition and its impact on the evolution and ecology of dung beetles. In L. W. Simmons, \& T. J. Ridsdill-Smith (Eds.), Ecology and Evolution of Dung Beetles (pp. 1-20). Oxford, UK: Blackwell Publishing.

Steinfeld, H., Gerber, P., Wassenaar, T., Castel, V., Rosales, M., \& Haan, C. (2006). Livestock's Long Shadow: Environmental issues and options. Rome, Italy: Food and Agriculture Organization of the United Nations.

Ueda, A., Dwibadra, D., Noerdjito, W. A., Kon, M., \& Fukuyama, K. (2015). Comparison of baits and types of pitfall traps for capturing dung and carrion scarabaeoid beetles in East Kalimantan. Bulletin of FFPRI, 14, 15-28.

Vaz-de-Mello, F. Z., Edmonds, W. D., Campo, F. C., \& Schoolmeesters, P. (2011). A multilingual key to the genera and subgenera of the subfamily Scarabaeinae of the New World (Coleoptera: Scarabaeidae). Zootaxa, 2854, 1-73.

Vieira, L., Louzada, J. N. C., \& Spector, S. (2008). Effects of degradation and replacement of Southern Brazil coastal sandy vegetation on the dung beetles (Coleoptera, Scarabaeidae). Biotropica, 40, 719-727.

West, C. P., \& Nelson, C. J. (2003). Naturalized grassland ecosystems and their management, p. 315-337. In R. F. Barnes, C. J. Nelson, M. Collins, K. J. Moore (Eds.), Forages: An Introduction to Grassland Agriculture. Ames, IA: Blackwell Publishing Professional. 